のケイ素の桩散係数の值は明らかでないが，一般に溶融金属中に おける元素の拡散係数の值は大略 $10^{-5}$ 位の值であり ${ }^{14)}$ ， ここで

14) W. Jost, "Diffusion in Solids, Liquids, Gases" p. 479, (1952) Academic Press.
えられた拡散係数の值は妥当な值と考えられる。これらの拡散係 数の值から，拡散の活性化エネルギーを求めると $5.1 \mathrm{kcal} / \mathrm{mol}$ となる。

（昭和 34 年 4 月，日化第 12 年会講演）

\title{
硫酸酸性溶液における二酸化イオウによる亜テルル酸の還元 およびセレンとテルルの分離への応用†
}

\author{
(昭 和 35 年 8 月 15 日 受理)
}

$$
\text { 浜田 圭之 助* }
$$

\footnotetext{
硫酸工場の副産物として得られるセレン含有の硫酸泥からのセレンの簡易精製法は1 3)，結局，硫酸酸性に扰ける互セ レン酸の二酸化イオウによる還元反応に州着される。

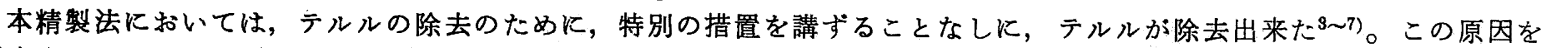
研究するために，まず塩酸酸性中における二酸化イオウによる亜テルル酸の還元反応を速度論的に研究したが8)，引き続 き首題の反応化ついて研究を行なった。

首題の反応は，亜セレン酸の場合の反応 ${ }^{2)}$ (可逆反応）执よ (゚テルルが硫酸に溶解する ${ }^{9,10)}$ ことから，可逆反応が予想 されたので，反応停止のため，反応物を水で希釈する方法は採用できなかったか，他の点では，第 1 報8)と同様にして実 験を行なった。

この反応が予想されたように，可逆反応であるか否かは，実験結果からは判断できなかったが，硫酸酸性溶液中の五七 レン酸の還元反応 ${ }^{2)}$ の場合とは, 甚だ異なる結果を得ると同時に，七レンとテルルが分離される原因が明白になった。す なわち, 亜セレン酸の場合には，亜せレン酸に関して，2次反応であったが，亜テルル酸の場合には，亜テルル酸に関し て1次反応であった。反応速度は重セレン酸の場合には $\left[\mathrm{H}^{+}\right]^{2}$ に比例したが，亜テルル酸の場合には $\left[\mathrm{H}^{+}\right]^{2} に$ 逆比例 することが判明した。結局, 硫酸溶液中においては, 水素イオンは, 前者の還元の場合には正触媒として作用するが，後 者の還元の場合には, 負触媒として作用するので, 水素イオン濃度を高くすることにより，亜セレン酸は還元されて，セ レンを析出するが，亜テルル酸は還元されないことが明らかになった。
}

\section{1 実験}

\section{$1 \cdot 1$ 試 䓠}

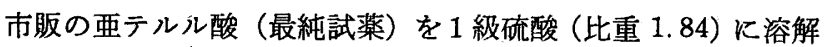
し,この溶液を蒸留水で希䣋して $0.138 \mathrm{~mol} / l$ および $0.069 \mathrm{~mol} / l$ の亜テルル酸の硫酸酸性溶液をつくった。

この溶液 $10 \mathrm{~m} l$ を水あるいは希硫酸で $200 \mathrm{ml}$ に希釈し, $\mathrm{pH}$ （精度 $\pm 0.1 \mathrm{pH}$ の $\mathrm{pH}$ メーターで測定した)が，それぞれ 0.51 , 0.23 拈よび -0.02 の溶液を調製した。水素イオン濃度は $\mathrm{pH}$ より計算により求めたが，それぞれ $0.31 ， 0.59$ 打よび $1.05 \mathrm{~g}$.

†本研究を「二酸化イオウによる亜テルル酸の還元反応の速 度論的研究 (第 2 報)」とする.

* 広島大学理学部化学教室: 広島市東千田町.

1) K. Hamada, Bull. Chem. Soc. Japan 34, 593 (1961).

2) K. Hamada, ibid. 34, 596 (1961). (以上, 日本化学会 第 13 年会講演).

3) K. Hamada, ibid. 34, 600 (1961).

4) Gmelins Handbuch der Anorg. Chem., 8 Auf. Nummer 11, Te. p. 130.

5) E. Diver, M. Shimose, Chem. News 51, 199 (1885).

6) Chem. Abst. 32, 4101 (1938).

7) T. L. Pokrovskaya, Zavodskaya Lab. 7, 15 (1938).

8）中国四国支部 10 周年記念大会講演; 浜田，日化 $82 ， 424$ (1961).

9) Gmelins Handbuch der Anorg. Chem., Nummer 11, Te p. 234.

10) A. Gutbier, Z. anorg. Chem. 31, 335 (1902). ion/lであった。

二酸化イオウは, 市販の液体二酸化イオウを水で洗浄して使用 した。

$1 \cdot 2$ 測 定

前述のよ5にして調製した $200 \mathrm{~m} l$ の亜テルル酸の硫酸酸性溶 夜を $300 \mathrm{ml}$ のエルレンマイャーフラスコに入れ，恒温槽中で恒 温に保つ $\left( \pm 0.1^{\circ} \mathrm{C}\right)$ 。同じ槽中に水の入った洗浄ビンを入れ，こ れを通した二酸化イオウを亜テルル酸の溶液に通す。所定時間経 過後, 析出したテルルを予め科量, 乾燥したガラスフィルター (1 G 4) で速やかに口別して, 水洗後, 空気乾燥器中で $110^{\circ} \mathrm{C}$ 前 後で乾燥し,ついで科量することにより析出したテルルを求めた。 この舞量值より, 反応達成率を求めて経過時間に対してプロッ トした。

反応達成率 $=($ 析出したテルル/溶液中の最初のテルル $) \times 100$

\section{2 結果および考察}

\section{$2 \cdot 1$ 亜テルル酸の初濃度の影響}

実験に使用した亜テルル酸の硫酸酸性溶液は $0.0069 \mathrm{~mol} / \mathrm{l}$ 打 よび $0.0034 \mathrm{~mol} / l$ である。それぞれの濃度の溶液について, 温 度 $\left(40^{\circ} \mathrm{C}\right)$, 水素イオン浱度 $(0.59 \mathrm{~g}$. ion $/ l)$ を一定にして, 所定 時間, 二酸化イオウを通し※1, 析出したテルルを前述のように処 置して (1・2 参照) 反応達成率に換算し，これを経過時間に対し

※1 二酸化イオウは, 反応の間中十分通しているので, 二酸化 イオウに関しては０次である。 


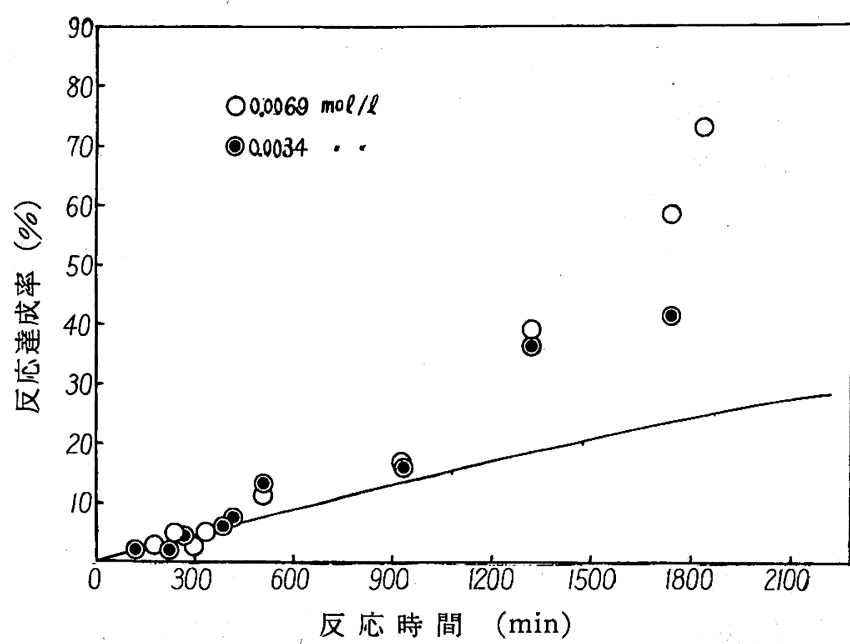

四 1 定温 $\left(40^{\circ} \mathrm{C}\right)$, 定水素イオン濃度 $(0.59 \mathrm{~g}$. ion $/ l)$ に打忛る $\mathrm{H}_{2} \mathrm{TeO}_{3}$ の $\mathrm{SO}_{2}$ による還元反応に及ぼす $\mathrm{H}_{2} \mathrm{TeO}_{3}$ の初濃 度の影響

てプロットしたものが，図 1 である。

図 1 に拈いて，反応初期についてのみ見ると，反応達成率は， 亜テルル酸の初濃度には無関係であることを示している。すなわ ち, 本反応は, 反応初期に打いては亜テルル酸に関して 1 次反応 であることを示している。これを数式で表わすと次のよ5になる。

$$
-\frac{\mathrm{d}(a-p)}{\mathrm{d} t}=\frac{\mathrm{d} p}{\mathrm{~d} t} \doteq k_{2}(a-p)
$$

ただし， $a:$ 垔テルル酸の初濃度 $\mathrm{mol} / l$,

$p: t$ 秒後の反応量 $\mathrm{mol} / l, k_{2}:$ 反応速度定数 $\mathrm{sec}^{-1}$

（1）式を積分すると

$$
t=\frac{2.303}{k_{2}} \times \log \frac{a}{a-p}=\frac{2.303}{k_{2}} \times \log \frac{1}{1-x}
$$

ただし， $x$ : 反応達成率（\%)，したがって $p=a x$

反応初期に打ける実験值たとえば $t=336$ 分 (20,160 秒) の時 反応達成率は $5 \%$ である。これらの值を（2）式に代入すると， 反応速度定数 $k_{2}=0.2536 \times 10^{-5} \mathrm{sec}^{-1}$ を得る。この $k_{2}$ の值を （2）“式に代入して，反応時間 $t$ に持ける反応達成率 $x$ を求め, $t$ に対して $x$ をプロットすると，図1の曲線を得る。すなわち, 本曲線は亜テルル酸に関する 1 次反応の理論曲線である。

反応初期においては，実験值はこの曲線と一致するが，反応が 進むに従って, 実験值は理論曲線より甚しく離反してくる※2。

\section{$2 \cdot 2$ 水素イオン濃度の影響}

亜テルル酸の初濃度 $(0.0034 \mathrm{~mol} / l)$, 温度 $\left(40^{\circ} \mathrm{C}\right)$ を一定にし て，水素イオン濃度をそれぞれ $0.31 ， 0.59$ 特よび $1.05 \mathrm{~g}$. ion $/ l$ として反応速度に抢よぼす影響を調べた。図2は，図1に拈ける と同様にして求めたものである※3。ただし四 2 の曲線 $\mathrm{D}, \mathrm{E} に つ$ いては後に述べる。時間の経過とと.もに理論曲線と実験值との離 反が甚しくなることは，因 1 の場合と同様である。

因 2 の曲線，A，B 执よび C に打ける速度定数と水素イオン 濃度の関係を表 1 に示す。

表 1 の最後の欄に示すよ 5 亿, 速度定数と, 水素イオン濃度の 自乗の積が一定である。このことは，本反応の速度が $\left[\mathrm{H}^{+}\right]^{2} に$ 逆比例することを示す。すなわち，水素イオンは，負触媒として

※2 この実驗値と理論曲線との離反についての考察は 2.4 亿拧 いて述べる。

※3 2.1 の項参照。

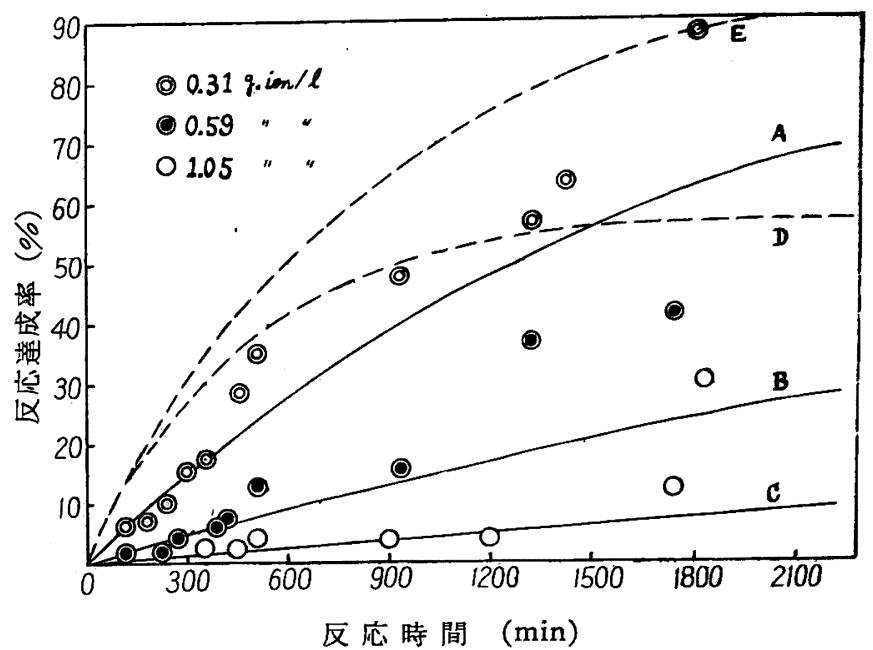

図 2 定温 $\left(40^{\circ} \mathrm{C}\right)$, 定初濃度 $(0.0034 \mathrm{~mol} / l)$ における $\mathrm{H}_{2} \mathrm{TeO}_{3}$ の $\mathrm{SO}_{2}$ による還元反応に及ぼす $\left[\mathrm{H}^{+}\right]$の影響

表 1 速度定数 $k_{2}$ と水素イオン濃度 $\left[\mathrm{H}^{+}\right]$との関係

\begin{tabular}{rrrrc}
\multicolumn{1}{c}{$\mathrm{pH}$} & {$\left[\mathrm{H}^{+}\right]$} & {$\left[\mathrm{H}^{+}\right]^{2}$} & $k_{2}\left(\mathrm{sec}^{-1}\right)$ & $k_{2} \times\left[\mathrm{H}^{+}\right]^{2}$ \\
\hline 0.51 & 0.31 & 0.0961 & $0.8871 \times 10^{-5}$ & $0.8525 \times 10^{-8}$ \\
0.23 & 0.59 & 0.3481 & $0.2538 \times 10^{-5}$ & $0.8830 \times 10^{-8}$ \\
-0.02 & 1.05 & 1.1030 & $0.0775 \times 10^{-5}$ & $0.8548 \times 10^{-6}$
\end{tabular}

作用する。硫酸酸性溶液における亜セレン酸の二酸化イオウによ る還元反応に招いては, 水素イオンは正触媒として作用する29。 したがって硫酸酸性溶液中においては水素イオン濃度を增すこと により，セレンとテルルを分離することができる。

\section{$2 \cdot 3$ 温度の影製}

亜テルル酸の硫酸酸性溶液に打いて, 垔テルル酸濃度 (0.069 $\mathrm{mol} / l)$ を一定とし, 水素イオン濃度 $0.31,0.59$ および $1.05 \mathrm{~g}$. ion $/ l$ の 3 種類の溶液について, 温度を $30^{\circ}, 40^{\circ}, 50^{\circ}$ および 60 ${ }^{\circ} \mathrm{C}$ として二酸化イオウを通し, 析出したテルルから反応達成率 を求め，これを反応時間に対して，プロットしたが(図は省略す) 反応初期に拈いては，実験值が非常に接近し，また反応が進むに したがって実験值が不連続な值をとり※4, 賦活エネルギーを求め ることができなかった。したがって，温度による反応速度定数の 変化を定量的に知ることはできなかった。しかしながらかなりの 温度差があっても，反応初期に秃いては反応速度にほとんど変化 がないことは，賦活エネルギーが非常に小さいことを示してい る。今かりに，賦活エネルギー $E \fallingdotseq 0$ と仮定すると

$$
k_{2} \propto e^{0}
$$

また $2 \cdot 2$ 項より, 反応速度定数は, 水素イオン濃度の自乗に反比 例するので，

$$
k_{2} \propto 1 /\left[\mathrm{H}^{+}\right]^{2}
$$

温度 $40^{\circ} \mathrm{C}$, 水素イオン濃度 $0.31 \mathrm{~g}$. ion $/ l$ の時の実験值を採り （3）扣よび（4）式を総合すると，速度定数の一般式として次式 を得る。

$$
k_{2}=0.8528 \times 10^{-6} \times 1 /\left[\mathrm{H}^{+}\right]^{2} \mathrm{sec}^{-1}
$$

\section{$2 \cdot 4$ 実験値の理論曲楾よりの離反に関する考察}

図 1 および図 2 に見られるよ5に, 反応初期に拈いては, 実験 值は亜テルル酸に関して 1 次の反応と考えた場合の曲線によく一

※4この理由については2.4において考察する。

※5（5）式は $40^{\circ} \mathrm{C}$ における式であるが，反応初期において は温度の影箩がほとんど表われないので速度定数の一般式 として・(5) 式が近似的に考えられる。 
致するが，しだいにこの曲線から離反してくる。この事実にうい て考察を進める。

亜テルル酸より, 二酸化イオウにより還元析出したテルルは, 希硫酸中に溶解する ${ }^{9,10)}$ 。また亜セレン酸の場合, 硫酸酸性中で は二酸化イオウにより析出したセレンは，硫酸に溶解して，可逆 反応 2 を呈する等の事実から，首題の反応も可逆反応であること が予想される。

$$
\mathrm{H}_{2} \mathrm{TeO}_{3}+2 \mathrm{SO}_{2}+\mathrm{H}_{2} \mathrm{O} \underset{k_{2^{\prime}}}{\stackrel{k_{2}}{\rightleftharpoons}} \mathrm{Te}+2 \mathrm{H}_{2} \mathrm{SO}_{4}
$$

ただし， $k_{2}$ : 正反応 $(\rightarrow)$ の速度定数, $k_{2}{ }^{\prime}:$ 逆反応 $(\leftarrow)$ の速 度定数

式で表わすと

$$
\frac{-\mathrm{d}(a-p)}{\mathrm{d} t}=\frac{\mathrm{d} p}{\mathrm{~d} t}=k_{2}(a-p)-k_{2}^{\prime} p
$$

ただし， $a:$ 亜テルル酸の初濃度, $p: t$ 秒後のテルルの析出量: （6）式の解を求めると

$$
t=\frac{2.303}{k_{2}+k_{2}^{\prime}} \times \log \frac{k_{2} a}{k_{2} a-\left(k_{2}+k_{2}^{\prime}\right) p}
$$

・反応初期に㧅いては，析出するテルルは極めて少量であるので, （6）式においい $p$ は無視できる。したがって近似的に次式が成 立する。

$$
\mathrm{d} p / \mathrm{d} t=k_{2} \cdot a
$$

本式は, 亜テルル酸に関して1次の式であるので, 反応初期にお いて実験値と 1 次の理論曲線がよく一致することが説明できる。 反応が進むにしたがって，析出するテルルはしだいに多量になる が，同時にテルルは凝集してくる。したがってその相対的な表面 積は小さくなる。その結果, テルルの溶解の速度(逆方向の反応) は減少するはずである※6。このよ5に反応の進行中に逆反応の速 度定数が変化するので，図 1 および図 2 に見られるように不連続 な実験值が得られることは自ら明らかである。

しかし析出したテルルの凝集のために逆反応の速度定数 $k_{2}{ }^{\prime}$ が 小さくなる時, その極限，すなわち $k_{2}{ }^{\prime}=0$ に打いては（6）式 は（1）式と全く同じものになる。したがっで時間の経過ととも に，不連続な值を採ることは，前述のよ5に説明できるが，実験 値が $k_{2}{ }^{\prime}=0$ の時の式，すなわち亜テルル酸に関する単純な 1 次 反応の式が表わす曲線（図 1 の曲線および図 2 の曲線 $A, B$ お びC）が示す反応達成率より高い值を示すことはあり得ない。

すなわち実験值と, 理論曲線（覀テルル酸に関する単純※7な.1 次反応の理論曲線）の不一致の原因を本反応が実際には，単純な 1 次反応ではなく，次に述べるような可逆反応の変形であるとい らことで説明しょうとしたが，ちまく説明できなかった。「本反 応は，実際には可逆反応であるが，析出してくるテルルの凝集の ためにテルルの相対的な表面積が減少し, 逆方向の反応速度が減 少するような反応である」。このように考えた場合すでに述へた とおり，反応初期の実験值と，理論曲線の一致扣よびしだいに実 験値が不連続になることは説明でさるが，実験值が理論曲線の示 すところの反応達成率より高い値を示すことは説明できない。た とえば，図2の点線で示す曲線 D, E は実験值を示すすのでは ないが, 前者は $k_{2}=1.555 \times 10^{-3} \mathrm{~min}^{-1}, k_{2}{ }^{\prime}=0.845 \times 10^{-3} \mathrm{~min}^{-1}$ として (7) 式より求めた可逆反応を表わす曲線で, 後者は $k_{2}=$ $1.155 \times 10^{-8} \mathrm{~min}^{-1}, \kappa_{2}^{\prime}=0$ として（2）式より求めたところの

※6 固態の溶解の速度は固態の表面積に左右される。

※7 正反応のみの反応で逆反応等の起らない場合の 1 次反応。
単純な 1 次反応の曲線であるが，曲線 D の示す可逆反応の逆反応 の速度定数 $k_{2}{ }^{\prime}$ がしだいに小さくなる場合, 反応達成率はDの示 す值より当然高くなる。しかし $k_{2}^{\prime}=0$ の極限の場合でも，反応 達成率は, 曲線 $\mathrm{E}\left(k_{2}{ }^{\prime}=0\right.$ のとさ, 曲線 $\mathrm{D}$ は，曲線 $\mathrm{E}$ となる）の 示す值をとるが，その示す值より高い值は採り得ない。

以上のように，実験値と理論曲線との不一致の原因は明らかで ないが, テルルの凝集を防ぐよ $5 ※ 8$, 実験上の工夫がなされれば, この点の解明に非常に有利であろ5。

\section{3 セレンとテルルの分離への応用}

セレンを精製するに際して, 最も厄介な不純物の一つは，テル ルである。このテルル除去のために種々の措置が講ぜられている ことは既に述べたが3)，著者の方法泉では，テルルに対して，特 別の顧虑を払うことなしに，テルルを除去することができた。本 実験により，この原因が明白になった。

亜テルル酸※9の硫酸酸性溶液に拈ける二酸化イオウによる還 元の速度定数 $k_{2}^{\mathrm{Te}}$ は (5) 式より

$$
k_{2}{ }^{\mathrm{Te}}=0.8525 \times 10^{-6} \times 1 /\left[\mathrm{H}^{+}\right]^{2} \quad \mathrm{sec}^{-1}
$$

要セレン酸 99 の硫酸酸性溶液の場合には, 速度定数 $k_{2} \mathrm{Se}$ は $\left.k_{2} \mathrm{se}=2.054 \times 10^{15} \times[\mathrm{H}]^{+2} \times \exp (-22,500 / R T) l . \mathrm{mol}^{-1} . \mathrm{sec}^{-12}\right)$

両式に見られるように $\left[\mathrm{H}^{+}\right]$扣よび温度が高いほど雨者の開き が大となる。

今かりに, 温度 $70^{\circ} \mathrm{C},\left[\mathrm{H}^{+}\right]=1.0 \mathrm{~g}$. ion $/ l$ 覀セレン酸の初濃度 $0.125 \mathrm{~mol} / l$ (覀テルル酸の場合, 覀テルル酸に関して 1 次反応で あるので，反応達成率は濃度に無関係である)の時※10, 亜セレン 酸および亜テルル酸の二酸化イオウによる還元反応の反応達成率 と反応時間との関係を，前 2 者の式から $k_{2} \mathrm{Se}, k_{2}{ }^{\mathrm{T} \theta}$ を求め，この 速度定数を基にして求めたものを※11図示すると, 図 3 に示すよ

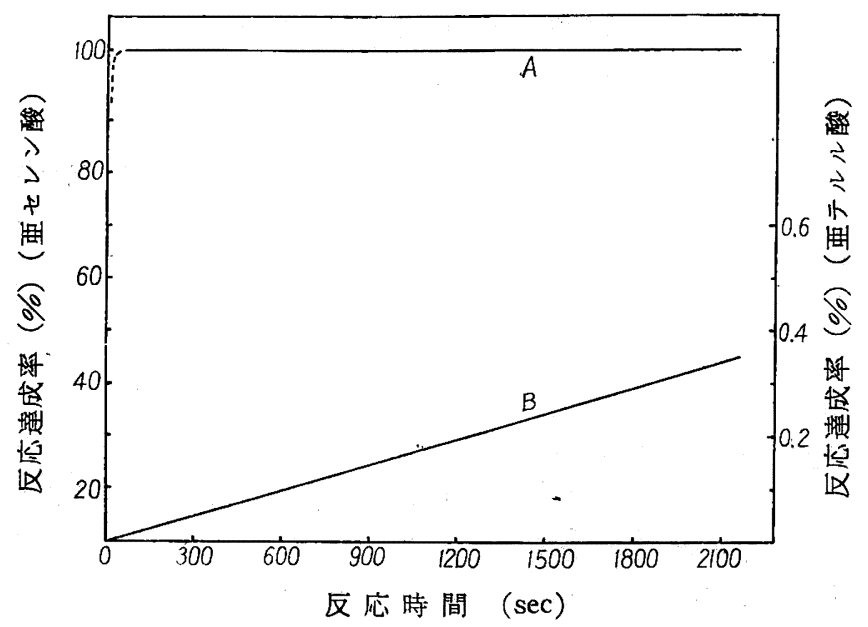

图 $3 \quad \mathrm{SO}_{2}$ とよる $\mathrm{H}_{2} \mathrm{SeO}_{3}$ と $\mathrm{H}_{2} \mathrm{TeO}_{3}$ の還元反応速度（硫酸中） $\mathrm{A}: \mathrm{H}_{2} \mathrm{SeO}_{3} ;$; 温度 $70^{\circ} \mathrm{C},\left[\mathrm{H}^{+}\right] 1.0 \mathrm{~g}$. ion $/ \mathrm{l}$, 初渡 $0.125 \mathrm{~mol} / \mathrm{l}$ B : $\mathrm{H}_{2} \mathrm{TeO}_{9} ;$ 溫度 $70^{\circ} \mathrm{C},\left[\mathrm{H}^{+}\right] 1.0 \mathrm{~g}$. ion $/ l$, 初潕度（任意迎常 $\mathrm{H}_{2} \mathrm{SeO}_{3}$ にくらべて極めて小)

※8 テルルの凝集を防ぐことは近反応の速度定数 $k_{2}^{\prime}$ を反応の 期間を通じて一定にすることである。もし，可逆反応です れば $k_{2}{ }^{\prime}$ が変化しなければ，曲線 Dに示すように平衡値を とる。

※9 セレン精製用の原料中のセレン，テルルは，発煙硫酸と硝 酸で処理されるので覀セレン酸怙よび亜デルル酸の硫酸酸 性溶液として存在する。

※10 これらの諸条件は, 七レンの精蛪 ${ }^{3)}$ の際の条件に大体一致 している。 
5になる。図 3 を見れば，セレンとテルルが分離されることは明 らかである。とくに亜セレン酸の還元は, 理諭的には数分間で達 成され (図 3 参照)，しかも通常要テルル酸の濃度は亜セレン酸に くらべて非常に小さいので，テルルの析出は完全に無視できる。 長時間二酸化イオウを通すことは，セレンの収率には無関係であ るのみならず, テルルの析出を增進する不利を招く結果となる。

\section{4 総括}

首題の反応は，亚セレン酸の硫酸酸性溶液に扣ける場合2) と類 似の反応様式を採ると思われたが，帮験の結果は，予想に反して 異なる反応様式であることが判明した。

特に, 水素イオンは亜セレン酸の場合には, 正触媒として働く

※11 要セレン酸の場合は文献 2) 参照, 正テルル酸の場合は (2)式より求めた。
が，亜テルル酸の硫酸酸性溶液に打ける還元反応に扣いては，負 触媒として作用することが明らかになった。この点を応用して， 亜セレン酸の中に, 亜テルル酸が混入していても, 硫酸酸性溶液 として高い水素イオン濃度で, 二酸化イオウにより還元すれば, セレンを析出して，しかもテルルの析出を防ぎ得る。

な敃実験結果について解明できない点もあるが，図3に見られ るように，亚セレン酸の還元反応は，非常に短時間で平衡値に達 するので，セレンとテルルの分離という目的から眺めれば，亜テ ルル睃の還元反応についても, 反応開始後, 極く短時間の間の反 応に注目すればよい。

反応の初期について見れば，首題の反応は，巠テルル酸に関し て 1 次の反応であると見なし $っ$ る。

種々御討論を賜わった広島大学理学部禰宜田博士に感謝す。

\title{
低沸点化合物の反応系外への放出による高圧水素還元用触媒，特に銅系触媒の活性急增 ${ }^{1}$,
}

(昭 和 36 年 3 月 10 日受理)

\author{
宮 文二・山西 卓郎・山 本 治*
}

\begin{abstract}
オートクレーブ $(550 \mathrm{cc})$ にナタネ脂肪酸メチル $150 \mathrm{~g}$, 銅クロマイト你煤 $4.5 \mathrm{~g}$ を入れ, $275^{\circ} \mathrm{C}$, 水素圧 $120 \mathrm{~atm}$ 邀元して高級アルコールをつくった。この反応の途中，反応で生じたメタノールを水素とともにオートクレーブ外に放出 し, 再び新水素を入れて反応を続行すると，その後の反応速度が非常に速くなった。反応速度は反応王を一定に保てば反 応物のヶン化価 (S. V.) 飞関し 1 次，すなわち $\mathrm{d}(\mathrm{S} . \mathrm{V}.) / \mathrm{d} t=-k(\mathrm{~S} . \mathrm{V}$.$) であるが，この k$ は $k=0.0124+0.00106 P$ で表わされる。ただ $k$ は放出後の速度定数 $(1 / \mathrm{min}), P$ は放出時の反応率 $(\%)$ である。この現象に対しメタノール が最も重要な役割りをする。つぎ原料にメタノールを添加し，反応が扣きない程度の低圧水素下にこれを加熱して 275 ${ }^{\circ} \mathrm{C}$ までに至らせる。この間の各温度でいったん添加したメタノールを放出， $275^{\circ} \mathrm{C}$ 飞到達後 $120 \mathrm{~atm}$ 下その温度での反

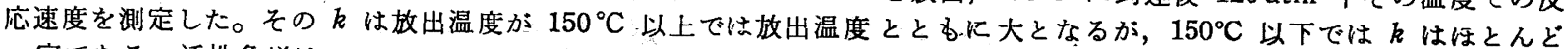
一定である。活性急增はメチルエステルの代わりに脂肪酸, あるいはそのブチルエステルを用いた反応に括いても認めら れる。また触媒が脂肪酸銅セッヶン, ラネー銅の場合も活性が急增する。さらにまた $\mathrm{Zn}-\mathrm{Al}-\mathrm{O}$ 触媒です顕著な活性增大 が認められる。ニッケル系触媒では認められない。これら一連の現象の真の原因は未だ不明である。
\end{abstract}

\section{1 緒言}

ナタネ脂肪酸メチル（以下 R.F.A.Me と略記する）を，銅ク ロマイト触媒2)を用いて高王水素䄐元し高級アルコールにする反 応に批いて, 反応の途中水素とともに反応で生成したメタノール を放出し，次に新水素を導入すると，それ以後の反応が予想以上 にきわめて速くなることが見出されたので，これに関連すること をさらにくわしく砳究した。

\section{2 試 料, 実験 法}

$2 \cdot 1$ 試 料

（1）銅クロマイト触媒; Calingaert 5 $5^{3)}$ の方法に準じてつく ったものである。（2）ラネー銅触媒；市肘品，50\% 銅含有。

$\dagger$ 本報を「触媒活性增大に関する研究（第1 報)」とする.

* 花王石鹼株式会社：和歌山市潜.

1）予報（研究速報）は宮, 工化 64, 240 (1961).

2) H. Adkins, R. Connor, J. Am. Chem. Soc. 53, 1091 (1931).

3) G. Calingaert, G. Edgar, Ind. Eng. Chem. 26, 878 (1934).
（3）銅セッケン; 試薬 1 級 $\mathrm{CuO}$ と蒸留ヤシ脂肪酸を当量ませ $150^{\circ} \mathrm{C} ， 30$ 分反応後口過した。（4）ラネーニッケル；市狙品。 （5）安定化=ッケル; 市販品。（6） $\mathrm{Zn}-\mathrm{Al}-\mathrm{O}$ 触媒; $\mathrm{Zn}\left(\mathrm{NO}_{3}\right)_{2}$. $6 \mathrm{H}_{2} \mathrm{O} 149 \mathrm{~g}$ を水 $2950 \mathrm{cc}$ にとかした液と $\mathrm{Al}\left(\mathrm{NO}_{3}\right)_{3} \cdot 9 \mathrm{H}_{2} \mathrm{O} 188 \mathrm{~g}$ を水 $3750 \mathrm{cc}$ に溶かした液とを合し，これに $\mathrm{Na}_{2} \mathrm{CO}_{3} 133 \mathrm{~g}$ を水 $500 \mathrm{cc}$ K溶かした液を加える。生ずる沈殿を遠心分離機を用いて $\mathrm{NO}^{-}$の認められなくなるまで水洗する。これを $105^{\circ} \mathrm{C} て ゙$ 乾燥後 $410 \sim 420^{\circ} \mathrm{C}$ に 2 時間やき粉础した。（7 ）ナタネ油脂肪酸メチル; ナタネ油とメタノールを $\mathrm{KOH}$ 触媒で常温エステル交換後水洗脱 水口過してつくった。その性状は，A. V. 0.15， S. V. 173, I. V. 103， OH.V. 1.7。（8）ナタネ油脂肪酸ブチル；ナタネ油脂肪 酸とブタノールを硫酸触媒でェステル化後アルカリ処理水洗蒸留 した。A.V. 0.33，S.V. 153， I. V. 90.6， OH.V. 0.66。（9） ヤシ油脂肪酸; ヤシ油を高圧分解後蒸留した。 N.V. 258, I. V、 10.3。（10）メタノール，ブタノール；市肘品試薬 1 級。(11) 水 素; 水電解によるもの。(12) 窒素; 市販品。

\section{$2 \cdot 2$ 実 験 法}

おもに $550 \mathrm{cc}$ 電位かきまぜ式オートクレーブを使用した。所 定の原料执よび蟲媒を入れ水素初圧 $10 \mathrm{~atm}$ 下に年温させる。70 